\title{
Intergenerational Educational Mobility and Identity: a French-Argentine Comparative Study
}

\author{
Miriam Aparicio \\ National Council of Scientific Research (CONICET). National University of Cuyo. Mendoza, Argentina
}

\begin{abstract}
This study forms part of the author's longstanding research regarding social, educational and professional mobility observed in Argentina across three generations, associated with the factor of Education and with the greater flow of immigrants in the last century. This research encompasses various smaller studies. Here we mention one, a French-Argentine comparative study in which we worked with PhDs from different institutions and different social science $\mathrm{PhD}$ programs. Our objective was: a) to analyze what factors (quantitative) and what reasons (qualitative) positively and negatively impacted professional pathways (career mobility); b) to observe the level of educational mobility present in families with $\mathrm{PhDs}$, taking the issue from different paradigms (reproductionist/interactionist): University of elites? University of the masses? The methodology was both quantitative and qualitative, using semi-structured surveys (which included open-ended statements so respondents could expand); the hierarchical evocation technique and interviews. Results: a) we observed the intergenerational educational mobility of $\mathrm{PhDs}$ (quantitative-descriptive level); b) we understood some of the "reasons" and "sense" that underlie said mobility and that have either acted as driving forces or have not acted as driving forces of social and cultural-educational promotion (qualitative level). c) We found similar levels of intergenerational educational mobility for $\mathrm{PhDs}$ in France and Argentina (graduates of various $\mathrm{PhD}$ programs). This result is interesting in the face of well-held myths of educational "hypo mobility", intergenerational drops in mobility, stagnation, a lack of educational/cultural promotion under "plafond" effects, or a saturation of degree holders, above all in developed countries. From the point of view of identity, this high level of intergenerational educational mobility impacted national, institutional and micro individual identity; three planes in sustained interaction using the author's theory: The Three Dimensional Spiral of Sense ((2015 a and b).
\end{abstract}

Keywords: Intergenerational educational mobility - University - Masses - Identity

\section{Introduction}

\section{Theoretical Framework}

\subsection{Intergenerational Educational Mobility and Career Mobility}

Our research on mobility reaches back decades to 1980 . Within this framework, the study carried out with PhDs belongs to the last phase. Previously, numerous studies have been carried out on educational and professional pathways for different populations, namely university populations (graduates from different universities, individuals who either abandoned their studies or who prolonged their studies beyond that stipulated by their Study Programs, students, university professors, high school teachers, researchers and $\mathrm{PhDs}$ ). We have also completed studies with university subjects in public and private workplaces (businesses, NGOs, etc.) so as to compare, among other aspects, profiles of achievement as they relate to conditioning factors.

One of these observed effects - besides Objective achievement, Subjective achievement, Socioeconomic level and Professional status - is Workplace insertion reached and promotions observed (Career mobility) ( Aparicio, 2005, 2007 a and b).

However, previously, we worked on Intergenerational Mobility, both from the Educational/Cultural and Professional points of view. This topic is very important in Argentina, a country which received one of the most important "waves" of European immigrants in history as a consequence of war and a favorable economy - causing the country to be known as the "breadbasket of the world" or "the country to make America." In fact, around 1930, the country changed its economic, social 
and cultural structure, becoming the fifth world power, in large part due to the arrival of immigrants and their accompanying work ethic (Germani, 1955; 1963; 1966; 1972; Aparicio, 1981; 1984a , 1984 b, 1984 c, 1985, 1987, 1988, 1990ª 1990 b, 1992, 1992/93; 1993).

In effect, the role of immigrants and their cultural ethos had a notable influence on this growth (Panettieri, 1966), as has been recognized in the national and international literature. Some arrived with an important work ethic but without economic means, many times fleeing from war. Nevertheless, moved by the n-ach (achievement needs) and a sense of struggle and effort, in just a short time they reached an important professional and, particularly, economic status (McClelland, 1961). In the second generation - the children of immigrants - many had already reached university level and with this, the immigrant dream came to fruition. "My son, the doctor" is a phrase that became immortalized by Argentine literature to describe parents' most relevant aspiration: that their descendants would reach the highest level of academic instruction. This was made possible by the fact that Argentina was, and continues to be, a country open to different cultures, where neither discrimination nor racism exist. For this reason it is considered an example of positive acculturation. In addition to this, we add the fact that university has been free and open to everyone since its origins (it is important to note that the University of Cordoba was the first university in the Viceroyalty of La Plata after the conquest of America).

Nevertheless, and though this goes beyond our objective here, it is necessary to point out that said immigration and the corresponding abrupt growth did have effects on individuals, who were made to adapt to cultural change, with all that this implies, and to gradually overcome anomie (Aparicio, 1984d, 1985c, 1996a, 1996b, 1997, 2014) and the so-called "status inconsistency" (Ellis, 1952; Ellis \& Kirbb, 1954; Jackson, 1962; Benoit-Smullyan, 1969; Heintz, 1965, 1970; Jackson \& Curtis, 1972; Jackson, 1962; Jackson \& Burke, 1965; Segal, 1967; Germani,1955, 1963, 1965, 1972; Aparicio, 2001).

The author dedicated many years to studying Implicit Intergenerational Mobility and its impact on national growth and in 2000 began to study personal/professional mobility. In this line, she translates R. Boudon's work, L'inégalité des chances. La mobilité sociale dans les sociétés industrielles (1973) into Spanish, published by Laia (Barcelona, 1983). At the same time, she completes a review of literature from the USA from the 1960s in which cultural mobility is considered a factor of social achievement, but also of national achievement, and is frequently linked to the psychosocial factor "Aspirations" and "n-Ach" (Keller \& Zavalloni, 1964; Krauss, 1964; Chinoy, 1952; Duncan, 1965; Elder, 1965; Levy-Leboyer, 1971; Jencks \& Brown, 1975; Benetton, 1975).

The recent shift in focus relates to the growing importance of Workplace insertion in the presence of new workplace demands. Added to this, still today, is an education which is inadequate for current market requirements, insufficient professionalization (especially in the social and human sciences), an increase in structural underemployment due to the influence of technology and economic factors, and the delocalization of businesses within a context of growing globalization, among other factors (Aparicio, 2000; 2003, 2001․ 2001 b, 2001c, 2002, 2004a , 2004b). This widespread scene impacts both biographical/professional and national identity, forcing actors to adopt new strategies to "survive" in the labor system. It also impacts opportunities for professional development and, among factors which indicate such development, occupational mobility. Dubar highlights these two aspects in different works: on the one hand, the need to once again address the issue of Professional promotion, overshadowed by the global situation and market difficulties, and on the other, the impact that these changes have at the level of biographical and relational identity (Dubar, 1991, 1992, 2000; Goffman, 1963).

Through the years, with the end of the phase of great Argentine growth, under the protection of hyperfunctionalist theories/criticism, the idea that the University was an institution open to elites, despite being free and - in most cases and in most political terms - with unlimited funds, extended (Rajneri, 1990). This would make access to university more difficult especially, as one could suppose, for those from families not culturally favored, that is to say those families in which parents and grandparents did not reach university level. In other words, we may think that well-known process of mobility had become stagnant (particularly at the university level).

In synthesis, the study of Intergenerational Mobility (Educational and Occupational) was addressed in the first phase of the author's research, inspired by the impulse of this topic in the USA under the Human Capital theory (Becker, 1964). Within this theory, Education is seen as an investment that brings about a better quality of life and other benefits. In a second phase (from the 1990s to the present), she dedicates her research to the issue of Career Promotion or Mobility, within the context of profound market changes, carrying out research with different populations. 
Nevertheless, she always incorporated the variable of Intergenerational Mobility (educational and occupational) into her work, with the objective of observing tendencies throughout the years and contrasting the mobility of different populations as it relates to various conditioning factors and effects.

The question we now ask then is: What happened with Intergenerational Educational Mobility for $\mathrm{PhD}$ populations? This line of research - in light of combined quantitative and qualitative methodologies and with three real generations (grandparents, parents, PhDs) - was introduced by the author in Argentina and in France (in this context there were already diagnoses with "figures" or statistics regarding PhDs, though with other theoretical-methodological focus) (Aparicio, I2009, 2012, 2015d).

The fact that we analyze PhDs, that is those who have reached the highest educational level in Argentina (in France the $3^{\text {rd }}$ cycle) has special significance.

\subsection{Intergenerational Mobility for University Students}

We address the problem in two instances: first, we refer to results provided by Cereq (in France) regarding the Diploma/Mobility relationship; secondly, we point out what questions oriented our analysis.

\subsubsection{Higher Education and Diplomas: Data}

The value of the diploma: access to higher education is becoming more and more commonplace. Since 1980, the number of individuals completing this level in France has quadrupled. Already in 1998, around 1 out of every 2 individuals had completed higher education.

Within this framework, obtaining a diploma continues to be a key factor, despite the devaluation of diplomas, and presents itself differently depending on the career program (Beltramo \& Paul,1994; Beltramo, Calmand \& Montjourides, 2008; Beret, 2002; Cereq, 1990; Cereq-Bref, 1998; Duhatois \& Maublancm 2006; Martinelli \& Perret. 1998)). The same phenomenon has been observed in Argentina: university graduates are higher up on the occupational scale than non-graduates and continue to value their diplomas.

In fact, in France, university graduates from Business and Engineering Schools are those least affected by structural unemployment, frequently occupying management positions and enjoying more stable positions. In Argentina, a strange tendency is observed with Engineering programs: engineers are in demand but currently enrollment in this discipline is decreasing in all universities.

Globally, those with a university degree rarely find themselves unemployed. Approximately half of these young people find employment immediately after finishing their studies and temporary employment is very rare (above all for Engineers).

We may infer from these findings that university diplomas protect against unemployment, though they are currently far from being a guarantee against relatively low salaries.

Salaries and gender. After three years of active life, net monthly salaries of young university graduates follow the same hierarchy of diplomas in France. Thus, one additional year of university studies is almost always valued in terms of salary, though differences between men and women do still exist, no matter the diploma obtained.

Entrance to professional life and unemployment: Those who graduate from Engineering and/or Business schools enter active life more favorably. Unemployment rates for these populations is almost cero, with $90 \%$ in non-temporary employment and, after three years of active life, almost $80 \%$ in France reach management status. In Argentina, the data follows the same path. For many years, no unemployment was observed for university graduates, though this peaked with the employment crisis of 2001-2002 (20\% of university graduates were unemployed).

As regards $\mathrm{PhDs}$, important differences are observed according to specialty. For all else, having reached the PhD does not have much influence on insertion into workplaces with better working conditions.

Nevertheless, it is necessary to point out that there are great differences according to specialty: unemployment rates are practically non-existent in Health fields in France, while on the contrary, they are very high for the Social and Human Sciences. Salaries in these disciplines are lower than for engineers and graduates from Schools of Administration or Business (around 8-10\% less); in Argentina this data is not available). 
There also exist differences between those who complete their university studies and those who abandon their programs without obtaining the diploma (absence of thesis).

At the Masters level, the same general situation is observed: the higher the diploma, the higher the salary, the lower the unemployment rate and the lower the percentage of temporary employment, though differences do always exist depending on the discipline.

As regards university, generally considered, obtaining a university diploma presents advantages according to the discipline: again, graduates in social and human sciences generally have more difficulties entering the market (particularly French graduates in art, psychology, history, and geography who -after three years on the market- have high unemployment rates, $15 \%, 12 \%$ and $11 \%$, respectively). Those who abandon their studies, as in the previous case, are sanctioned in the context of the labor market. In Argentina, those working in the field of education have difficulties with the aforementioned aspects and, particularly, with salaries.

This information demonstrates that, even under non-optimal market conditions, added to the effects of globalization: a) a university degree represents a " plus », though it no longer ensures important comparative benefits; b) this "plus" is much lower for the social and human science disciplines.

\subsubsection{Questions Guiding our Analysis}

Firstly, the idea has spread that University is for the elites in both countries, under the influence of hyperfunctionalist/reproductionist approaches which emerge with force in France in the 1970s (Bourdieu \& Passeron, 1984). Education and the academic institution -previously considered from points of view of interactionism, theories of Human Capital and the so-called "Investment" theories (as opposed to the "Consumption" theories Mingat \& Eicher, 1982) as motivators of human development were seen as devices of reproduction of the dominant classes (Bisseret, 1968; Giroux, 1983).

In addition, taking into account the democratization of teaching, a phenomenon more and more widespread since the 1960s, many individuals not previously incorporated into the educational system (minorities, black people, women, working classes, ...) gradually find their way into University. Thus, enrollments take off and the idea of the University of the masses begins to take hold, with its positive and negative aspects, especially in the labor market (Jarousse \& Mingat, 1988;; Eicher, 1973; Levy-Garboua, 1976).

The issue, within this context, is if in the highest level of instruction there is greater access to University as compared to previous generations. Recent data from Argentina show that Intergenerational Mobility remains at the university level. The Observatorio de Villa María (Córdoba) demonstrates that a very high percentage reaches university studies for the first time. For its part, the University of Buenos Aires -with 400,000 students- demonstrates with its most recent statistics that (July 2017) that more than half of its students are first generation university students (their predecessors did not reach the university level). Its Rector, Dr. Barbieri, stated on Radio Mitre that "According to data from the University of Buenos Aires, half of its students are the first in their families to go to university" (...) "The role of the university is to reach out to all sectors. Each year, there are more and more individuals attempting to reach the university level of education."

Secondly, we asked ourselves if this phenomenon took on the same dimensions in Argentina as in France, keeping in mind that in France thousands of PhDs graduate each year (many of them in social and human sciences), while in Argentina graduation rates in these fields has only recently begun to grow in the last decades (PhD programs in these areas were shut down in the 1970s under the military dictatorship). For this reason, we expected to find a greater increase in individuals in Argentina reaching the doctorate as compared to their parents and grandparents.

Continuing with the Argentine case, where the "cultural ethos" has always given education a unique position as a tool of progress, we asked ourselves if this ethos currently continued to push individuals to the highest academic level, despite the structural limitations non-existent in the last century. In other words: faced with a market of conflict and marked structural unemployment, do individuals still wish to attain this level, knowing full well it will be difficult to find a position in the labor market fitting of their education? In France, for its part, the market is also facing serious issues (the delocalization of businesses for one, with the subsequent increase in unemployment), which means that not all $\mathrm{PhDs}$ can get the positions they desire (Aparicio \& Cros, 2015).

Faced with this panorama: 
What moves or motivates people to carry out $\mathrm{PhD}$ studies and, particularly, $\mathrm{PhD}$ studies in the social and human sciences, where demand is limited to the State (in general, the majority will be university professors and researchers) where the structural limits are marked, as there are not enough positions to absorb supply (Aparicio, 2014). On the other hand, European statistics show that Engineering and Business Schools especially are those which offer a more promising future in terms of occupational development (income, position, quality of life) (Aparicio, 2009).

What leads someone to desire to reach an educational level greater than that of his or her family, without linking this specifically to economic benefit? What image or representation is held regarding PhD programs? Is it still considered a type of passport to the future, despite contextual circumstances which are not always favorable? (Moscovici, 1961) Is this imaginary found in accordance with the real situation?

\section{Hypothesis}

-PhD saturation in the French context, more marked than in the Argentine context, leads to the observation of lower degrees of relative intergenerational educational mobility.

-In both Argentina and France, higher or fourth level education is still accessible today, within a socio-economic context which is quite unfavorable, for individuals whose families did not reach this highest level of educational instruction.

\section{Methodology}

\subsection{Population:}

We worked with $\mathrm{PhD}$ students and $\mathrm{PhDs}$ in the social sciences and humanities in Argentina (UNCuyo, PhDs in Education and Social Sciences) and France (one university located in Paris and one located in the province). We took as our sample students who had entered starting in 2005 and later. In this paper, we refer to results found in our Argentine context, with only mentions made to similarities found respect to studies carried out in France.

\subsection{Techniques}

Among the quantitative techniques used was a semi-structured interview of PhD students and PhDs (2005-2014). Among the qualitative techniques utilized were a semi-direct interview, word association (Doise, Clemente \& Lorenzi-Cioldi, 1992; Wagner \& Hayes, 2005; Wagner, Valencia y Elejabarrieta, 1996) and hierarchical evocation (Abric, 2001). In this paper, we will focus on the descriptive-quantitative segment.

\section{Results}

Mobility, diploma and $\mathrm{PhD}$ education: These three aspects are important for the synthesis of individual and contextual aspects. We have addressed the question of statistics in the theoretical framework, with the official statistics from France contributed by Cereq (Center for the Study and Research of Data). We observe results for the different institutions studied.

In the words of the PhDs, one of every two graduates estimates that the degree obtained at the undergraduate level has been an engine for occupational mobility (this is observed particularly for those who have experienced internal mobility within the same workplace organization). Nevertheless, this has not always been associated with greater workplace Satisfaction (Aparicio, 2016 a, c). Nor is there a correlation between those experiencing objective occupational mobility (changing positions to one higher up) and a feeling of having been promoted, as they frequently relate this promotion to different aspects of the position itself (workplace environment, demands, recognition, respect, etc.) (Aparicio, 2016b).

More specifically, they were asked if they consider that the doctorate will have an influence on their general objective situation over the next ten years and in their disciplinary field. Secondly, they were asked if they consider that having finished the doctorate can be considered a vector of Socio-professional mobility, having already experienced positive changes in their career. The majority of respondents - between $60 \%$ and $70 \%$, both for Argentine programs and French programs - consider that there has been some change in their career since the start of said studies, whether in income or position, though with differences between men and women (Cf. Aparicio,2015d, chapter 3, Trajectoires et identités. Also, Dupray \& Moullet, 2005). Nevertheless, some report not having experienced any promotion. 
Individuals will continue to value doctoral programs, despite contextual limitations, and this probably leads them to choose to carry out studies at this level, exceeding the level reached by their families. In other words, this could result in Intergenerational Educational Mobility, with subsequent impacts on identity.

\section{Our findings in percentage terms $(\%)$}

1. We were able to access our object of analysis in the various institutions, finding strong similarities between them (the percentages of mobility of grandparents to PhDs and of parents to PhDs in the Education PhD program in Argentina are very similar to those found in the French provincial University).

2. The following results were obtained for Argentina (National University of Cuyo); we will briefly highlight those results obtained at the French provincial University.

In Cuyo, for PhDs in Education, there are graduates whose parents have no formal education (4.7\%), while $32.6 \%$ have parents who finished primary education, $18.6 \%$ secondary education and $44 \%$ university education. That is to say, almost $50 \%$ of graduates do not have parents who reached the university level. The figures found at the PhD level -the highest educational level in Argentina- are very similar to those found at the University of Buenos Aires (UBA) among undergraduate students, in line with the Rector's recent comments.

Also in Cuyo, but for PhDs in Social Sciences, there are no graduates with parents with no formal education and there is a lower percentage of students who have parents with only a primary level of education, as compared with the Education $\mathrm{PhDs}$. Here, the majority of parents $(42.9 \%)$ completed secondary education, while $28.6 \%$ reached the university level.

At the French provincial University, whose identity we protect, we recorded the following percentages by level:

There are no parents with no formal education, while $37.5 \%$ completed primary education and another $37.5 \%$ completed secondary education. $75 \%$ of the graduates' parents can be found within this range. Only $25 \%$ of parents had reached the university level.

3. The PhD, even in social and human sciences - less promising fields in the Market according to studies and statistics continues to be attractive to the university public, overcoming the economic angle and resting upon obtaining a degree.

[1] References

[2] Founding fathers are cited.

[3] Aparicio, M. (1981). Subdesarrollo: situación y perspectiva desde una teoría psicosocial. Sociológica, 6/7, 3-47.

[4] Aparicio, M. (1984a). La sociología de las desigualdades hoy. Dos explicaciones para la relación desigualdad social/desigualdad escolar. Cuadernos del CIC, Centro de Investigaciones Cuyo. Nota.

[5] Aparicio, M. (1984b). Educación, Ocupación y Desarrollo. Puesta a prueba de una hipótesis a través de una encuesta. Cuadernos del CIC, 12,102-166.

[6] Aparicio, M. (1984c). Cambios asincrónicos en la Argentina vistos a través de la movilidad y la participación. Cuadernos del CIC, 6, 65-102.

[7] Aparicio, M. (1984d). Cambio y conflicto a través de los perfiles de inconsistencia de status. Asimismo, Desequilibrio de status, anomia y marginalidad. Actas del Primer Congreso de Psicología Social, 78-92. Universidad de Belgrano, Buenos Aires.

[8] Aparicio, M. (1984e). Una mirada crítico-retrospectiva al problema de la medida de la movilidad social. CIC. 118. Actas del Segundo Congreso Argentino de Enseñanza y Aplicación de la Metodología de Investigación en Ciencias Humanas y Segundo Congreso Argentino de Enseñanza y Aplicación de la Metodología de la Investigación Social.

[9] Aparicio, M. (1984f). Problemas metodológicos en la medida de la movilidad social. Mendoza, PRED (Programa Educación y Desarrollo). Actas VIII Jornadas de Investigaciones, 24-31, Consejo de Investigaciones. Universidad Nacional de Cuyo.

[10] Aparicio, M. (1985a) ¿Herencia cultural o herencia social? Cuadernos del CIC, 13, nº especial, 39-76. 
[11] Aparicio, M. (1985b). Movilidad estructural y movilidad neta a partir de una configuración de movilidad observada. Actas de IX Jornadas de Investigaciones. Consejo de Investigaciones. Universidad Nacional de Cuyo, 41-48.

[12] Aparicio, M. (1985c). Conformismo anómico y conducta desviada como un problema de personalidad, cultura y sociedad. Actas de IX Jornadas de Investigaciones, 97-114. Consejo de Investigaciones. Universidad Nacional de Cuyo.

[13] Aparicio, M. (1987). Un análisis de los supuestos teóricos de la movilidad social. PRED, publicación especial, $55 \mathrm{p}$.

[14] Aparicio, M. (1988). Algunas consideraciones sobre la relación Educación/Ocupación desde la perspectiva de la movilidad socio-profesional. Actas del II Seminario Argentino de Orientación Vocacional/Ocupacional "Hacia una Argentina con identidad". Universidad Nacional de Cuyo, 169-186.

[15] Aparicio, M. (1990a). La escuela y la génesis de las desigualdades sociales. Revista de Ciencias de la Educación y Formación Docente, 1, 53-78.

[16] Aparicio, M. (1990b). Hacia un análisis crítico de la teoría de la subcultura de clases desde la perspectiva de la movilidad social. Investigaciones en Sociología, 85-146.

[17] Aparicio, M. (1992/1993). La devaluación de los diplomas y algunos de sus efectos sociales. Investigaciones en Sociología, 22-23, 33-68.

[18] Aparicio, M. (1992). ¿Universidad de masas? Un estudio en cifras para las dos últimas décadas en la Argentina. Serie Investigaciones, $n^{\circ}$ especial. Mendoza: Ed. Pontificia Universidad Católica Argentina, 1-96.

[19] Aparicio, M. (1993). Hacia un balance crítico de algunas teorías sobre la escolarización. Revista EducaciónCuyo, 3, 197-276.

[20] Aparicio, M. (2000). Le chômage structurel. Réponses psychosociales d'après deux 'patterns' d'inconsistance de statut. In B. Gangloff, Satisfactions et souffrances dans le travail, Paris, L'Harmattan, 7-15.

[21] Aparicio M. (2001a). Identidad y "sindrome de realización", La Psicología Social en México, vol 7, 771-776.

[22] Aparicio, M. (2001b). Commentaire à l'article Le chômage structural. Réponses psychosociales d'après deux 'patterns' d'inconsistance de statut. Travail et Emploi, 87, juillet.

[23] Aparicio, M. (2003). Calidad y Universidad. Un estudio sobre graduados a la luz de un modelo multidimensional (1985-2002). UTN. Mendoza: ZETA, 186 pp.

[24] Aparicio, M. (2004a). Réussite, exclusion et logiques associées dans le système productif anticipé par le système éducatif. Une analyse à partir du modèle consommation-investissement. In A. Lancry \& C. Lemoine, La personne et ses rapports au travail. Paris: L'Harmattan, 59-63.

[25] Aparicio, M. (2004b). La psychologie de sous-emploi structurel. Une étude dans des organisations à la lumière de modèles attributionnels. In: A. Lancry \& C. Lemoine, La personne et ses rapports au travail. Paris: L'Harmattan, 49-68.

[26] Aparicio, M. (2005). « Les facteurs psychosociaux en relation avec la réussite universitaire et professionnelle ». 2a Doctoral Thesis. Mention: Très honorable avec félicitations du jury (800 p., 2 Vol.). Doctorat en Sciences de l'éducation. Université René Descartes. Paris V. Sorbonne, France.

[27] Aparicio, M. (2007a). Les facteurs psychosociaux à la base de la réussite universitaire et professionnelle: aspects psychologiques et organisationnels. Habilitation à diriger des recherches, Field: Psychology Science. Post-Doctoral Level. Université de Lille3, France.

[28] Aparicio, M. (2007b). Mobilité et réussite universitaires et professionnelles. Du niveau macro au niveau micro. Habilitation à diriger des recherches, Field: Education Science. Post-Doctoral Level. Université París X, Nanterre, France.

[29] Aparicio, M. (2008 ${ }^{\mathrm{a}}$. Trayectorias universitarias. Un análisis a la luz de metodologías cuantitativas. Institutional Project. Universidad Nacional de Cuyo, restricted version. Vol. I. Mendoza: ZETA, 294 p.

[30] Aparicio, M. (2008b). Trayectorias universitarias: Un análisis a la luz de metodologías cualitativas. Institutional Project. Universidad Nacional de Cuyo, restricted version. Vol. II. Mendoza: ZETA, 438 p.

[31] Aparicio, M. (2008). Causas de la Deserción en Universidades Nacionales. San Juan: Ed. UNSJ.

[32] Aparicio, M. (2009). Conference. Congrès de l'Ecole de Gestion: Nouvelles carrières. Nouvelles compétences. Les trajectoires universitaires et professionnelles: entre formation et travail, Faculté des Sciences de la gestion, Université de Rouen, 13-14 mai.

[33] Aparicio, M. (2009). Le doctorat : Une étude comparative franco-argentine. Paris. Marie de Paris. 
[34] Aparicio, M. (2012). Crise d'identité et devenir professionnel des étudiants qui sont engagés dans un doctorat en éducation/formation. Une approche comparative franco-argentine. Biennale internationale de l'éducation, la formation et des pratiques professionnelles., Cnam, París. Du 3 au 6 juillet.

[35] Aparicio, M. (2014). Postgraduate Level and its Impact on Academic Studies and Professional Careers, Social and Job Mobility and Identity. A Study about PhD Graduates and PhD Students at UNCuyo, in the Light of a sui generis Paradigm. Journal of Educational and Social Research, 4, 2, 474-477.

[36] Aparicio, M. (2014). Satisfaction, Professional Mobility and Leadership in Academic-Scientific Organisations, Journal of Health Science, Vol 2, 3, 135-145.

[37] Aparicio, M. (2015a). Towards a sui generis Systemic Theory: The Three-Dimensional Spiral of Sense. A Study in Argentina Applied to Identity and Professionalization (Article 1). Asian Academic Research Journal of Social Sciences \& Humanities (AARJSH), 2, 7 (December 2015), 246-282.

[38] Aparicio, M. (2015b). The Theory of the Three-Dimensional Spiral of Sense: An Application with special Reference to Identity and Professionalization in other Disciplinary Areas (Article 2) Asian Academic Research Journal of Social Sciences \& Humanities (AARJSH), 2, 7 (December 2015), 194-245.

[39] Aparicio, M. (2015c). Mohamed Cherkaoui: His Thoughts and His Impact and Validity in Argentina In: GEMASS \& G. Manzo (Ed.), Paradoxes, Mechanisms, Consequences: Essay in honor of Mohamed Cherkaoui. University of Oxford: Bardell Press (Set of 2 Volumes); (Volume II: Social Mechanisms, 7-20).

[40] Aparicio, M. \& Cros, F. (2015d). Trajectoires et identités. Un avenir incertain pour les docteurs? Paris: L'Harmattan. Collection Éducation et Sociétés.

[41] Aparicio, M. (2016a). Satisfaction and Professional Mobility. A French Argentine Study about PhD, in the Light of a Sui Generis Paradigm. Sociology Study, July 2016, 6, 7, Serial Number 62, 470-477.

[42] Aparicio, M. (2016b). Professional Mobility and "Objective" and "Subjective" Satisfaction. A Non-Linear Analysis from The Theory of The Three-Dimensional Spiral of Sense in Population of Doctors, European Journal of Interdisciplinary Studies. September - December, 3(1), 52-62.

[43] Aparicio, M. (2016c). Doctoral Education: An Academic and Labor Market "Plus"? An analysis using the Theory of the Three Dimensional Spiral of Sense, International Educational Scientific Research Journal, 2(10), 123127 , October.

[44] Abric, J-C. (2001). (Ed.). Prácticas sociales y representaciones. México: Coyoacán /Embassade de France.

[45] Barbieri, A. La mitad de los alumnos de la UBA son de primera generación de universitarios. https://radiomitre.cienradios.com/la-mitad-de-los-alumnos-de-la-uba-son-primera-generacion-deuniversitarios/Consultado 29julio2017

[46] Becker, G. (1983). El Capital Humano. Madrid: Alianza [1a. ed., 1964].

[47] Beltramo, J.-P., Bourdon, J. \& Paul, J.-J. (1994). L'emploi scientifique à I'horizon 2000. Essai de prospective. Formation Emploi, $n^{\circ} 45$, janvier-mars, 33-50.

[48] Beltramo, J.-P., Calmand, J. \& Montjourides, P. (2008). La politique d'insertion des docteurs en entreprise: fondement et efficacité. Marseille: Cereq.

[49] Beret, P. (2002). Mobilités des chercheurs des entreprises et mutations de la recherchedéveloppement. Formation Emploi, avril-juin, $n^{\circ} 78$, pp. 35-52.

[50] Benoit-Smullyan, J. (1969). Status, Status Types and Status Interrelation-ships, Amer. Sociol. Rev., 9, 151-161.

[51] Bisseret, N. (1968). La naissance et le diplôme. Les processus de sélection au début des études universitaires. R. Française de Sociol., 9, $\mathrm{n}^{\circ}$ spécial, 185-207.

[52] Boudon R. (1973). L'inégalité des chances. La mobilité sociale dans les sociétés industrielles, Paris, PUF. Traduction by Miriam Aparicio, 1983, Barcelona: LAIA.

[53] Bourdieu, J-P. \& Passeron, J.-C. (1984). Les Héritiers. Paris: Minuit.

[54] CEREQ (1990). Les jeunes docteurs et l'emploi (1990). Formation par la recherche, n 31, Spécial 10ème Anniversaire, juin, pp. 17-38.

[55] CEREQ-BREF (1998). Emploi public, emploi privé. La difficile conversion des titulaires de thèse, octobre, $\mathrm{n}^{\circ}$ $146,1-4$.

[56] Duhautois, R. \& Maublanc, S. (2006). Chercheurs dans le privé : la place des docteurs. Connaissance de l'emploi, février, 26, $4 \mathrm{p}$.

[57] Doise, W., Clemente, A. \& Lorenzi-Cioldi (1992). Représentations sociales et analyses de données. Grenoble: Presses Universitaires de Grenoble. 
[58] Dubar, C. (1991). La socialisation. Construction des identités sociales et professionnelles. Paris: Colin.

[59] Dubar, C. (1992). Cheminements professionnels et mobilités sociales. Paris: La Documentation française.

[60] Dubar, C. (2000). La crise des identités. Paris: PUF.

[61] Dupray A. \& Moullet S. (2004), Femmes à l'entrée dans la vie active : un retard salarial en partie inexpliqué, $N E F, n^{\circ} 12$

[62] Eicher, J.-C. (1973). L'éducation comme investissement : la fin des illusions ? Revue d'Économie Politique, $n^{\circ}$ spécial.

[63] Ellis, C. (1952). Social Psychological Correlates of Upward Social Mobility among Unmarried Career Women, American Sociological Review, 17, 558- 563.

[64] Germani, G. (1965). Les effets de la mobilité sociale sur la société, Sociologie du Travail, 4, 383-415.

[65] Germani, G. (1963). Los procesos de movilización e integración y el cambio social, Desarrollo Económico, 3 , 403- 421.

[66] Germani, G. (1972). La estratificación social y su evolución histórica en Argentina. Argentina Conflictiva, estudios sobre problemas sociales argentinos, 87-113.

[67] Germani, G. (1955). Estructura social de la Argentina. Buenos Aires: Raigal.

[68] Giroux, H. (1983). Teorías de la reproducción y la existencia en la nueva sociología de la educación: un análisis crítico. Harvard Education Review, 3, 61-108.

[69] Goffman, E. (1998). Estigma: La identidad deteriorada. Buenos Aires: Amorrortu.

[70] Heintz, P. (1970). Hacia un paradigma sociológico del desarrollo con especial referencia a América Latina. Buenos Aires: Instituto.

[71] Hollinshead, A.; Ellis, R. \& Kirbb, E. (1954). Social Mobility and Mental Illness, Amer. Sociol. Rev., 19, 577-584.

[72] Jackson, E. (1962). Status Consistency and Symptoms of Stress, Amer. Sociol. Rev., 27, August, 469-480.

[73] Jackson, E. \& Burke, P.-J. (1965). Status Consistency and Syntoms of Stress: Additive and Interaction Effets, Amer. Sociol. Review, 30, 556- 564.

[74] Jackson, E. \& Curtis, R. (1972). Effets of Vertical Mobility and Status Inconsistency: A Body of Negative Evidence, Amer. Sociol. Review, 37, 701-713.

[75] Jarousse, J.-P. \& Mingat, A. (1988). Un réexamen du modèle de gains de MINCER. Revue Économique, 37, 6, décembre.

[76] Jencks, C. S. \& Brown, M. (1975). The Effects of Desagregation on Student Achievement: Some New Evidence from the Equality Educational Opportunity Survey, Sociology of Education, 48, 126-140.

[77] Keller, S. \& Zavalloni, M. (1964). Ambition and Social class: A Respecification, Social Forces, 43, 58-70.

[78] Krauss, I. (1964). Sources of Educational Aspirations among Working-class Youth: Amer. Sociol. Review, 29, 867- 879 .

[79] Lensky, G. (1954). Status Crystallization: a Non-vertical Dimension of Social Status, Amer. Sociol. Rev., 4, August, 405-413.

[80] Levy-Garboua, L. (1976). Les demandes de l'étudiant ou les contradictions de l'université de masse, $R$. Française de Sociol., 17, 1, 53-80.

[81] Levy-Leboyer, C. (1971). L'ambition professionnelle et la mobilité sociale. Paris: PUF.

[82] Martinelli, D., Paul, J.-J. \& Perret, C. (1998). Emploi public, emploi privé. La difficile conversion des titulaires de thèse. CEREQ-BREF, octobre, $n^{\circ} 146,1$.

[83] McClelland, D. (1961). The Achieving Society. Princeton, Van Nostrand Company, Inc.

[84] Mingat, A. \& Eicher, J.-C. (1982). Higher Education and Employment Markets in France. Higher Education, 37,6, novembre.

[85] Moscovici, S. (1961/1976). La psychanalyse, son image, son public. Paris: PUF.

[86] Observatorio de Estudiantes de Villa María (Córdoba) (2017). Estudiantes universitarios sin antecedente familiares. UNVM.

[87] Panettieri J. (1966). Los trabajadores en tiempos de la inmigración masiva en la Argentina 1870- 1910: Universidad de La Plata.

[88] Passeron J-C. (1989). Biographies, flux, itinéraires, trajectoires, Revue Française de Sociologie, 31, 3-22.

[89] Rajneri, J. (1990). Qué hacer con las universidades. Historia de matrículas e ingresos irrestrictos. Diario La Nación. 
[90] Segal, D. R. (1967). Status Inconsistency, Cross Pressures, and American Political Behavior, Amer. Sociol. Review, 37, 352- 358.

[91] Silva, A.M. \& Aparicio, M. (Eds.) (2015d). International Handbook about Professional Identities. EEUU: Academic and Scientific Publishing.

[92] Wagner, W. \& Hayes, N. (2005). Everyday Discurse and Common Sense. The Theory of Social Representations. New York: Palgrave MacMillan.

[93] Wagner, W., Valencia, J. \& Elejebarrierta, F. (1996). Relevance, Discurse and the "Hot" Stable core of Social Representations. A Structural Analysis of Word Associations. British Journal of Social Psychology, 35, 331-354.

\section{Highest educational level reached by parents}

(The following tables are not essential for publication as their data has been incorporated into the text.)

Table 1: Degree Program versus Highest Educational Level Reached by Parents (UNCuyo, Argentina) (q11)

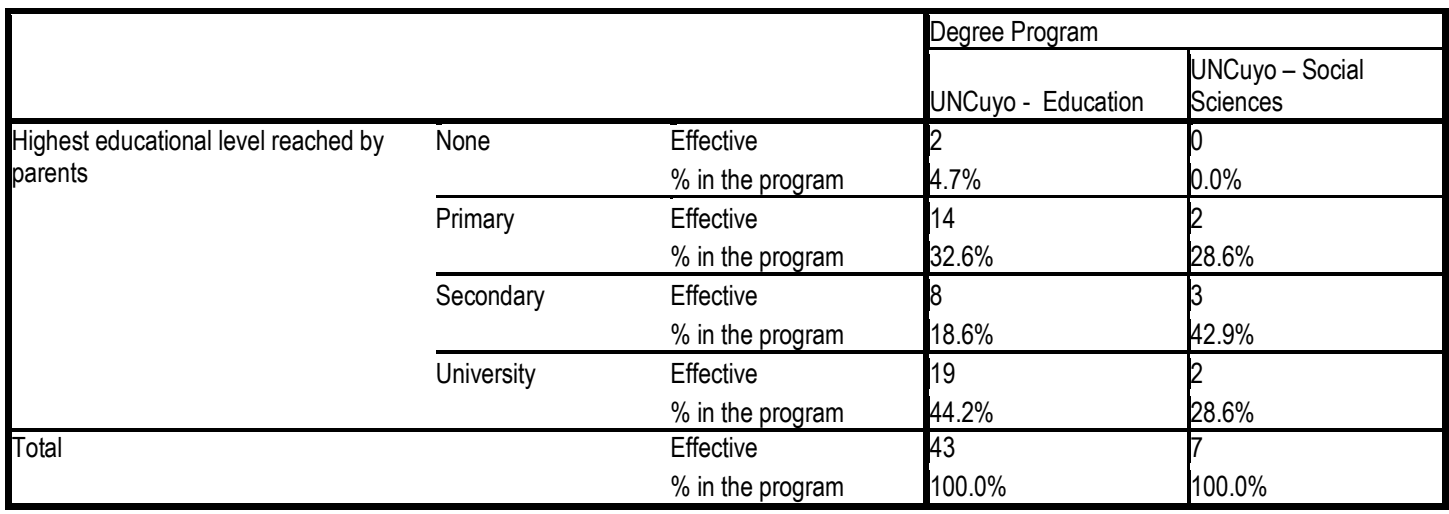

Table 2: Degree Program versus Highest Educational Level Reached by Parents (French University) (q11)

\begin{tabular}{|c|c|c|c|}
\hline & & & Degree Program \\
\hline & & & Education Sciences \\
\hline \multirow[t]{8}{*}{ Highest educational level reached by parents } & None & Effective & 0 \\
\hline & & $\%$ in the program & $0.0 \%$ \\
\hline & Primary & Effective & 9 \\
\hline & & $\%$ in the program & $37.5 \%$ \\
\hline & Secondary & Effective & 9 \\
\hline & & $\%$ in the program & $37.5 \%$ \\
\hline & University & Effective & 6 \\
\hline & & $\%$ in the program & $25.0 \%$ \\
\hline \multirow[t]{2}{*}{ Total } & & Effective & 24 \\
\hline & & $\%$ in the program & $100.0 \%$ \\
\hline
\end{tabular}

